\title{
The Nevada Test Site Neutron Log Calibrator
}

Joseph R Hearst

February 1994

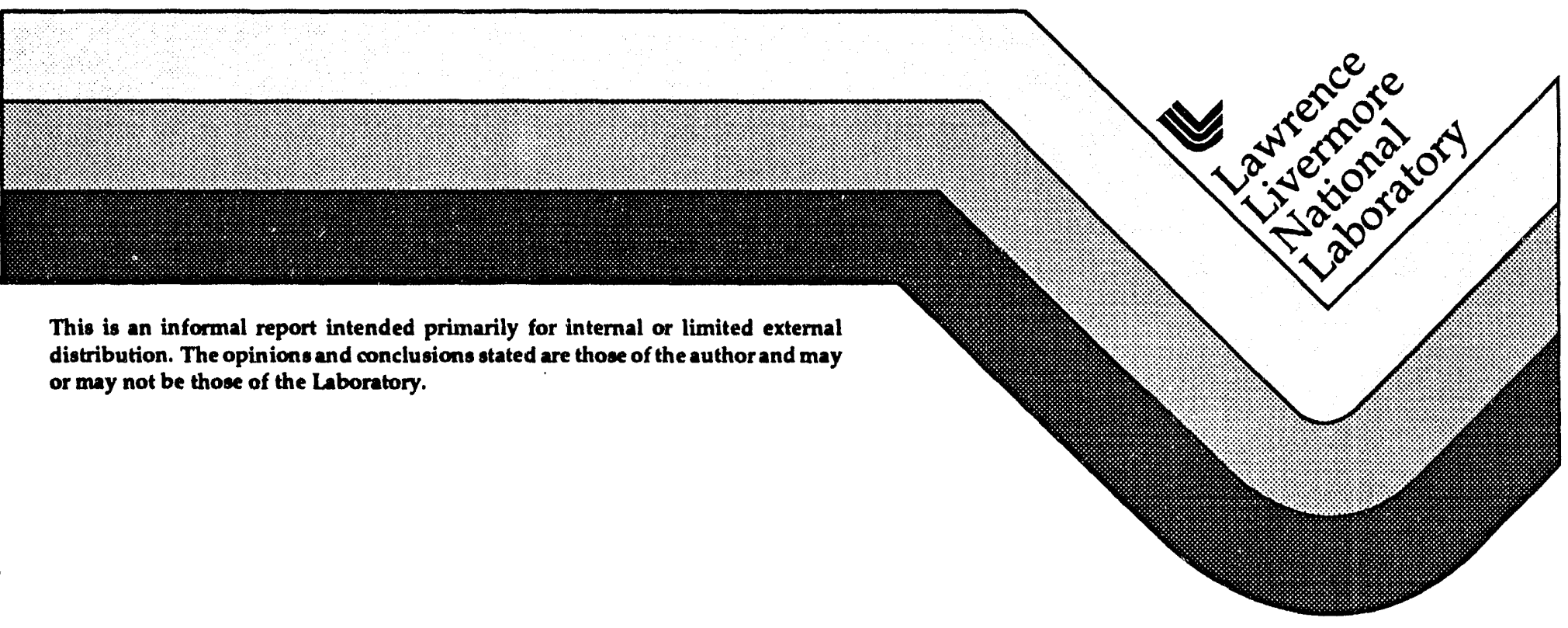




\section{DISCLAIMER}

This document was prepared as an account of work sponsored by an agency of the United States Government. Neither the United States Government nor the University of California nor any of their employees, makes any warranty, express or implied, or assumes any legal liability or responsibility for the accuracy, completeness, or usefulness of any information, apparatus, product, or process disclosed, or represents that its use would not infringe privately owned rights. Reference herein to any specific commercial products, process, or service by trade name, trademark, manufacturer, or otherwise, does not necessarily constitute or imply its endorsement, recommendation, or fa voring by the United States Government or the University of California. The views and opinions of authors expressed herein do not necessarily state or reffect those of the United States Government or the University of California, and shall not be used for advertising or product endorsement purposes.

This report has been reproduced directly from the best available copy.

A vailable to DOE, and DOE contractors from the Onice of Scientific and Technical Information

P.O. Box 62, Oak Ridge, TN 37831

Prices a vailable from (615) 576.8401, FTS 626-8401

Available to the public from the

National Technical Information Service

US. Department of Commerce

5285 Port Royal Rd.

Springfield, VA 22161 


\title{
The Nevada Test Site Neutron Log Calibrator
}

\author{
Joseph R Hearst
}

\begin{abstract}
A new calibrator for neutron logs in large-diameter holes has been built at the Nevada Test Site. It consists of two cylinders, each made of six wedge-shaped cells. The outside diameter of each cylinder is $4.8 \mathrm{~m}$, and the inside diameter is $2.4 \mathrm{~m}$; the height is $2.3 \mathrm{~m}$. The cells were filled with mixtures of hydrated alumina, tabular alumina, sand, and water to achieve a large range of bulk density and hydrogen index. A new calibration algorithm, using three-dimensional interpolation in hydrogen index-gap-density space has been developed to determine hydrogen index from log data. There is evidence that the new algorithm is slightly more accurate than the previous algorithm.
\end{abstract}

\section{Introduction}

During the evaluation of a proposed site for an underground nuclear test at the Department of Energy's Nevada Test Site (NTS) it was important to measure the water content of the geological formation in which the test was to be executed. The most satisfactory method for this measurement is the neutron log (Hearst and Nelson, 1985) This is a measurement system in which a neutron source and detector are mounted in an instrument (a sonde) which is lowered into a borehole by a multi-conductor cable, and the number of neutrons detected is used to infer the hydrogen index $\left(\mathrm{I}_{\mathrm{H}}\right)$. The hydrogen index is defined as the hydrogen content per unit volume as a fraction of the hydrogen content of fresh water.

Many geophysical service companies offer neutron logs, but those logs are calibrated for the conditions that occur in the petroleum industry: liquid-filled boreholes with diameters between 7 and $40 \mathrm{~cm}$, drilled in saturated media. At NTS many of the boreholes of interest are air-filled, with diameters as large as $3.65 \mathrm{~m}$, drilled in partiallysaturated media. Consequently the commercial equipment and calibration procedures are not suitable for NTS conditions.

Moreover, many commercial systems detect thermal neutrons. The formations at NTS contain significant amounts of boron and gadolinium (Diment, 1959), which absorb thermal neutrons and substantially reduce the accuracy of thermal neutron measurements. Furthermore, in most modern commercial neutron logging systems the hydrogen index is determined from the ratio of the neutron count rates in two detectors; this method is unsatisfactory in air-filled holes (Alger et al., 1972). Therefore we found it necessary to modify both the equipment and the calibration methods of commercial neutron logging systems before we could apply them to NTS conditions.

Several parameters besides water content influence the count rate observed in a neutron log. The most important of these are the bulk density of the formation and the

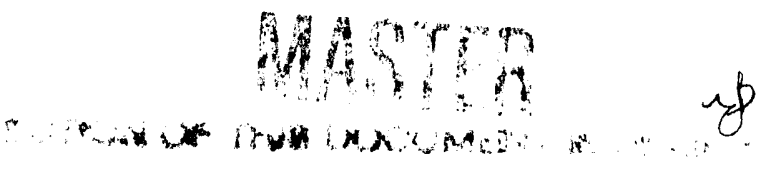


gap between the measuring device (the sonde) and the wall of the borehole. Since there is a wide variation in density in NTS formations, and there are often large washouts in NTS boreholes, resulting in substantial gaps between the sonde and the formation, it is necessary to build a calibrator that takes into account density and gap as well as hydrogen index.

Our original calibrator consisted of twelve stations, each containing material mixes having different values of hydrogen index and bulk density. Each station was made of fifteen aluminum cells, $30 \mathrm{~cm}$ square by $180 \mathrm{~cm}$ high, held together in a 3 X 5 array with steel chains (Hearst, 1979; Hearst et al., 1981, Axelrod and Hearst, 1984.) Figure 1 shows this calibrator, known as the Hydrogen Content Test Facility (HCTF.) The flat face of the array was assumed to be a reasonable simulant of the wall of a 2-to 3-m-diameter air-filled borehole. To simulate a water-filled hole, a water tank was placed against the face of the array and pressed tightly against the face; the sonde was then placed in the tank and forced against the wall touching the calibrator. To simulate a $30-\mathrm{cm}$-diameter hole, one square cell was removed from the array, and the sonde placed in the resulting square hole.

Although the HCTF was used for many years, we recognized that it was at best a mediocre simulator, especially because the water tank was a very poor approximation to a water-filled hole, and the flat face of the array and the flat side of the square hole were poor approximations to the curved wall of a real borehole. Eventually, we were able to construct a calibrator that is a far more satisfactory approximation to real conditions. This report describes the design and construction of that calibrator, and the first calibrations performed in it.

\section{The logging sondes:}

Figure 2 is a sketch of a conventional neutron logging sonde. The neutron source and detector(s) are usually contained in a pad that is forced against the wall of the borehole. Neutrons flow from source to detector through the formation and through the borehole fluid; a small fraction reach the detector. Normally the fluid is water, and the attenuation of the neutrons is much more rapid in water than in the formation, so most of the neutrons that reach the detector have traveled through the formation. If the borehole is air-filled however, the neutrons travel much more readily through the air than through the formation, and the measurement is invalidated.

To deal with this problem we surrounded a conventional sonde, which had a source-detector spacing of $45 \mathrm{~cm}$, with a polyethylene shield to prevent transport of the neutrons through the borehole. Our original shield was an aluminum shell, filled with a boron-loaded polyethylene paste. The shell was approximately $15 \mathrm{~cm}$ in diameter, so that it could be used in a $30-\mathrm{cm}$ diameter borehole. The sonde was an obsolescent commercial version with a single detector that was designed to detect epithermal neutrons, to avoid the absorbtion of thermal neutrons by boron and gadolinium. A wheel on a spring-loaded 
arm was attached to one end of the sonde, and was used to measure the gap between the sonde and the wall of the borehole. The sonde, called the ENP, is shown in Figure 3.

The ENP was used in 2-to-3 m diameter boreholes for several years, and it became clear that hydrogen indices measured with it in the larger holes disagreed with those measured in nearby smaller holes. A simple experiment, using a pile of wet sandbags to simulate a 2-m hole, showed that the count rate was substantially greater in the simulated hole than on a flat surface. Both experiments and Monte Carlo calculations indicated that the part of the hole in contact with the sonde was the main contributor to the effect; not the side of the hole farthest from the sonde. The experiment indicated that adding $7.5 \mathrm{~cm}$ to the thickness of the shield would be sufficient to eliminate the effect.

A new shield was built, consisting of a solid block of polyethylene. Its front face (in contact with the borehole) was shaped to a radius of curvature of $76 \mathrm{~cm}$. Away from the face, the polyethylene was $15 \mathrm{~cm}$ thick. In addition, a second gap indicator was added to the other end of the sonde. The resulting system, called the ENS, is shown in Figures 4 and 5. When tested in the same configuration as the experiment that showed the hole-size effect for the ENP, the hole-size effect was greatly reduced. The ENS is now the standard system for holes at NTS greater than $1 \mathrm{~m}$ in diameter. There was still, however, evidence from Monte Carlo calculations that the flat face of the HCTF was not completely satisfactory for the simulation of a hole with a finite radius of curvature.

\section{Design of the new calibrator}

To solve the problem of the finite radius of curvature we constructed a new calibrator, the Hydrogen Content Test Unit (HCTU.) Two borehole diameters were chosen: $2.4 \mathrm{~m}$ and $30 \mathrm{~cm}$. Each was to be capable of being filled with water at need. Densities and hydrogen indices were chosen to span the range expected at NTS. Specific values were chosen to to facilitate the use of Monte Carlo calculations to develop interpolation methods. Twelve combinations were selected, and the calibrator was designed in the form of two cylinders, each with six wedge-shaped cells. The outside diameter of the cylinder, $4.8 \mathrm{~m}$, and the height, $2.3 \mathrm{~m}$, were chosen as a compromise between economy and the desire to make the calibrator appear effectively infinitely large to a logging system.

Because the calibrator was designed for use with epithermal neutrons it was not necessary to match the elemental composition of NTS formations. The cylinders were made of aluminum, which has approximately the same neutron scattering cross-section as silicon The thickness, $1.25 \mathrm{~cm}$. was necessary for mechanical strength. For good calibration, there should be no aluminum, which in small quantities is essentially transparant to epithermal neutrons, between the sonde and the material mix. Therefore a 3-mm-thick window was milled into the face of the cylindrical inner wall of each cell in the central area to be contacted by the sonde. 
To simulate 30-cm-diameter holes, a 30-cm-diameter, 3-mm wall-thickness tube was placed in the center of each cell. When the $2.4-\mathrm{m}$ hole is being used, a tube filled with the same material as the rest of the cell is placed in the $30-\mathrm{cm}$ hole. In the corner of each cell a 5-cm-diameter tube was placed to be used in checking the uniformity of the fill material. The wedge-shaped cells were built separately and attached to one another and to the floor of the building with mastic to provide a water seal. Figure 6 shows the cylinders during construction, and Figure 7 shows the completed HCTU.

\section{Filling the cells}

Most neutron-log calibrators are made either of a porous solid or a uniform granular material, saturated with water. To obtain the range of density and hydrogen index needed for the HCTU we had to use a mixture of materials of different densities and hydrogen indices. It is very difficult to prepare and emplace a large-volume uniform mixture of materials of different density. To prevent the material from settling after the emplacement is completed the mixture should be vibrated during emplacement. and then low-density particles tend to rise to the surface. A series of studies and small-scale experiments helped us choose satisfactory materials.

The materials chosen were silica, tabular alumina, hydrated alumina, and water. Table 1 shows the properties of these materials. To achieve the desired density range, materials were used in two sizes: sand and powder. A mixture of materials in powder form resulted in lower bulk density than a mixture of the same proportions of the same materials in sand form. The sand-size silica was Overton sand. Specification sheets for the materials are shown in the Appendix.

After many experiments and much study of the literature it was clear that it would be impossible to emplace uniform mixtures of the volume needed to fill a cell.

Consequently we filled the cells in horizontal lifts, each approximately $15 \mathrm{~cm}$ thick. Each lift was mixed separately to ensure that the same amount of each material was in each lift. This procedure assured us that the fill could not be nonuniform on a scale greater than the lift thickness.

Each lift was emplaced and leveled, and then the cell was vibrated for one to two hours by pneumatic vibrators attached to the outside walls of the cell. During vibration the lift height was measured every 10 minutes and the lift was leveled every 15 minutes. At the end of the vibration a final height measurement was taken at several places on the surface of the lift. The bulk density of each lift was computed from the area of the cell, the height of the lift, and the mass of material emplaced.

The hydrogen index of the mixture was computed from the material properties shown in Table 1, and then checked by taking several samples from each lift and measuring the weight fraction of water evolved by heating the samples in the laboratory. The hydrogen index was then determined by multiplying this weight fraction by the bulk density. 
The lifts coniaining liquid water were filled in the same manner as the other lifts: by preparing mixtures for each lift and then emplacing them. When the work was completed it was realized that some of the cells containing water were not fully saturated. Therefore it was possible that with the passage of time the water in those cells could migrate to the bottom of the cells and cause nonuniformity and changes in the hydrogen index in the region sampled by the logging sonde. To remedy this situation one cell, No. 6 , was saturated with water by filling it from the bottom. No action was taken on the other water- containing cells.

After filling was completed, as-built values of hydrogen index and bulk density were computed. The recipes for the mixtures and the as-built properties of the cells are shown in Table 2. A report including detailed histories of the filling of each cell was prepared (O'Laughlin and Walker, 1990.) This report includes plots of density and hydrogen index obtained by the methods described above as a function of depth for each cell. In some cases the mean value of bulk density or hydrogen index of an individual lift was as much as $15 \%$ greater or less than the mean value of the entire cell. Most of the variation in these properties is caused by variation in the measured bulk density. It is believed that there is an uncertainty of $1 \mathrm{~cm}$ in the measured thickness of an individual lift. Almost all of the variation in the bulk density can be attributed to this uncertainty: that is, the range of bulk density obtained by assuming a $1 \mathrm{~cm}$ uncertainty in the lift thickness almost always included the mean value for the entire cell.

After all filling had been completed small-diameter density and moisture logs were run in the 5-cm-dia corner holes of each cell (Carlson, 1992). These logs were not wellcalibrated for absolute values of the properties measured under the conditions of the measurement in our cells, but they were excellent indicators of uniformity. Standard deviations of hydrogen index and bulk density were always less than $5 \%$ of the mean values.

\section{Calibrations}

The conventional sonde is removed from its shield and placed in a plastic verifier (Fig. 8) before and after each downhole run to verify its stability. The verifier includes two drawer-like blocks called "baffles", which can be raised or lowered to change the count rate. Each position of the verifier: both baffles up, one baffle up, and both baffles down, is assigned an arbitrary number of "API" units which historically were related to measurements in the American Petroleum Institute calibration models ("test pits") in Houston. The currently-assigned values of API units for the verifier cannot be related to the test pit units in any plausible way, and so should be considered arbitrary. If, however, the sonde is placed in the verifier before and after the calibration at the HCTU, and the count rate in the HCTU is multiplied by the ratio of API units to count rate in the veritier, the HCTU data can be converted to units that are independent of source size and drift in the electronics of the sonde. Field data are converted to API units in the same way, which permits the calibration in the HCTU to be used for field data even though there are small 
changes in behavior of the sonde. The standard position of the verifier for conversion is with both baffles up; the other two positions are used only to check linearity of the count rate.

Since the sonde is forced against the borehole wall during field operation it is important that the sonde be in firm contact with the calibrator wall during calibration. Special jigs were built for both the $2.4 \mathrm{~m}$ hole and the $30 \mathrm{~cm}$ hole; they are shown in Figures 7 and 8. Each jig spans the hole to provide pressure on the sonde. It is also necessary to calibrate at various values of gap between the sonde and the wall. Shims of various thicknesses are placed at each end of the sonde, and the sonde is again forced against the wall to provide these calibrations. Calibration data are shown in the appendix.

The dependence of the count rate with the sonde placed against a given cell is fairly linear with gap, but the slope of the line depends on density and hydrogen index. Figure 9 shows a typical plot of count rate vs gap.

In the past, we fitted the intercepts of the twelve lines of count rate vs gap to an equation in density and hydrogen index (Axelrod and Hearst, 1984.) Knowing the slope of the gap vs count rate curve, a measured count rate could be corrected for slope appropriate to the measured gap to obtain the intercept, and this intercept could be inserted in the equation to obtain the hydrogen index.

Since, however, the slope depends on the hydrogen index, this procedure required iteration. We developed a complex surface to describe the dependence of slope on density and hydrogen index. To obtain hydrogen index from a triad of values of density, count rate and gap we entered the equation fitted to the intercepts with the measured density and a count rate corrected for an arbitrary value of the slope, and obtained a value of hydrogen index. Next we interpolated on the surface to determine the slope at the measured density and hydrogen index. The count rate was corrected for the new value of slope and the iteration continued until acceptable precision was achieved.

For HCTU data, we decided to use grid interpolation instead. A grid of hydrogen index as a function of density and count rate (actually logarithm of count rate) obtained during calibration is prepared for each of several values of gap. For each gap the count rate at the values of density and hydrogen index for each cell is obtained by using the fitted slope and intercept for that cell. Then the triad of values of density, count rate, and gap measured at each depth in the borehole are used to to obtain hydrogen index by linear interpolation in three dimensions. After the value of hydrogen index is obtained, the bulk density is corrected for hydrogen index and the interpolation is repeated. Typical grids at zero and maximum acceptable gap are shown in Figures 10 and 11.

When this procedure was tested with a $\log$, we found higher hydrogen index than that found by the fitting procedure in the HCTF at low hydrogen index, and lower hydrogen index than using the HCTF at high hydrogen index. We could not tell whether this difference was caused by the new calibration data or the new gridding procedure, so 
we applied the gridding method to the HCTF as well. The resulting log lay between the original HCTF log and the new HCTU log. Figure 12 shows the three logs.

Since the HCTF log from the fitting procedure differs from that using the gridding procedure, we processed a set of raw HCTF calibration data with gaps different from those used for making the grids through both methods. We then compared the results with the known values of hydrogen index. Neither set agreed perfectly with the known true values, but there was no systematic difference. The grid results were, overall, slightly closer to the true values. This experiment indicated that the grid procedure was at least as good as the fitting procedure.

When we compared the logs shown in Fig. 12 to known values of water content in cement surrounding the borehole (Burkhard, 1993) we found that the new HCTU log was in better agreement with the known data than the HCTF log.

Both the experiment in the simulated hole, discussed above, and Monte Carlo calculations had indicated that the count rate for the original sonde: the ENP, at a given hydrogen index below about 0.3 , would be higher in a hole like that in the HCTU than on the flat surface of the HCTF. The shield of the ENS was designed to eliminate this difference. The observation of slightly higher count rate for the ENS in the HCTU indicates that the shield was not quite thick enough. This is not surprising, since the amount of shielding that could be placed at the front of the sonde was limited by the requirement of a $76 \mathrm{~cm}$ radius of curvature for the ENS. In fact, the discrepancy justified the construction and use of the HCTU.

\section{Conclusions}

The new NTS neutron log calibrator, the HCTU, has been constructed and tested, and used for calibration of the ENS neutron logging sonde. A three-dimensional gridding procedure, rather than a polynomial fit to count rate and a surface for gap corrections, has been used to calibrate the sonde. The results of this calibration procedure appear to be an improvement on previous methods. The HCTU is a satisfactory calibrator for neutron logging systems at the NTS.

\section{Acknowledgements}

John Conaway, Mark Mathews, and Robert Deupree of Los Alamos National Laboratory and Richard Carlson of Lawrence Livermore National Laboratory made major contributions to the physics design of the HCTU. James Barber of Raytheon Services Nevada was the engineer who made the entire operation possible; he designed the cells, found the materials, and devised the filling methods. Clay OLaughlin of Raytheon Services Nevada was in charge of the filling operation and designed and executed the laboratory experiments that led to the final choice of materials. This work was performed under the auspices of the U. S. Department of Energy by Lawrence Livermore National 
Laboratory under contract No. W-7405-Eng-48. The work was supported by the LLNL Nuclear Test Containment Program. 


\section{RETERENCES}

Alger, R. P., S. Locke, W. A. Nagel and H. Sherman, 1972 The Dual-Spacing Neutron Log - CNL, Jour. Petr. Tech. v. 24, p. 1073,)

Axelrod, M. C. and J. R Hearst, 1984; Calibration of a Neutron Log in Partially Saturated Media, IV: Effects of Sonde-Wall Gap, Trans. Soc. Prof. Well Log Analysts, 25th Annual Logging Symposium, New Orleans, June 10-13, Paper Q.

Burkhard, N. R., (1993) An In-Situ check of the Epithermal Neutron Log Calibration; Proc. 7th Symp. on Containment of Underground Nuclear Explosions, Seattle, Sept. 1317, Paper J-5.

Carlson, R. C., 1992, Personal communication.

Diment, W. H., 1959; Trace Element Memoranda Nos. 996, 997 and 998, U. S. Geological Survey, Washington, D. C.

Hearst, J. R;1979; Calibration of a Neutron Log in Partially Saturated Media, Trans. Soc. Prof. Well Log Analysts, 20th Annual Logging Symposium, Tulsa, June 3-6, Paper B.

Hearst, J. R, P. W. Kasameyer and L. A. Dreiling, 1981; Calibration of a Neutron Log in Partially Saturated Media, Part II: Error Analysis, Trans. Soc. Prof. Well Log Analysts, 22nd Annual Logging Symposium, Mexico City, June 23-26, Paper QQ.

Hearst, J. R and P. H. Nelson, 1985, Well Logging for Physical Properties, McGraw-Hill, New York.

Keys, W. S. 1990, Borehole Geophysics Applied to Ground-Water Investigations, U. S. Geological Survey, Denver. 


\section{APPENDIX}

This appendix shows the specifications for the materials used to fill the HCTU. No specifications are available for tabular alumna. 
Hydrated Alumina Sand

Harcros Chemicals Inc

17421 F. 174h. Sintc $1(x)$

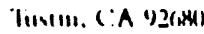

HARCROS

$1.171+/ 5+4.4-82(x)$

CHEMICAL GROUP

\section{TECHNICAL SERVICE BULLETIN}

IINICROS 30

TYPICAL ANALYSIS

Cliemical

AVAILADILITY

APILICATIONS

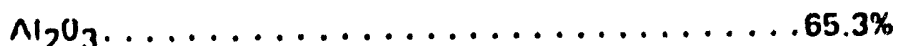

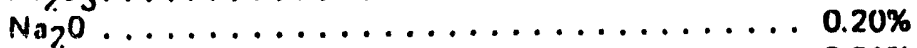

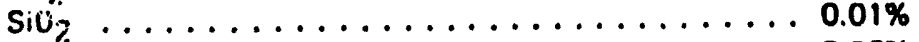

$\mathrm{Fe}_{2} \mathrm{O}_{3} \ldots \ldots \ldots \ldots \ldots \ldots \ldots \ldots \ldots \ldots \ldots . \ldots \ldots \ldots$

Moisture . . . . . . . . . . . . . . . $0.04 \%$

L.0.1. . . . . . . . . . . . . . . . . . 34.5\%

Pliysical Size-On 100 Mesli(U.S. Standard) $11 \%$

On 200 Mesil

O11 325 Mesh

Bulk clensity, loose

Specilic gı ovily

$97 \%$

GO IIs/cu. It.

$2.12^{\circ}$

Slipulung Point-Bauxite, Arkansos

Packing-Bulk

Aluminum Clin!nicals

Titania Production 
Hydraced Alumina Flour

Hurerns Chemiculs lue

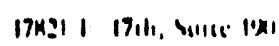

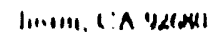

I. IIA/9.11-H3(1)

\section{$\because \square$ \\ HARCROS. \\ CHEMICAL GROUP}

\section{TECHNICAL SERVICE BULLETIN}

MRCROS 330 ALUMINA TRIIYYURAIE

TYIPICAL CIIEMICAL ANALYSIS:

$\mathrm{AL}_{2} \mathrm{O}_{3}$

$\mathrm{SIO}_{2}$

$\mathrm{FE}_{2} \mathrm{O}_{3}$

$\mathrm{NA}_{2} \mathrm{O}$ (TOTAL)

$\mathrm{M}_{2} \mathrm{O}$ (SOLUBLE)

LOSS ON ISNITION (1000 $\mathrm{C})$

FREE MOISIURE $\left(110^{\circ}\right.$ C. $)$ q

\section{PERCENT}

64.9

0.02

0.02

0.35

0.02

311.6

0.2

PHYSICAL PROPERTIES:

SCREEN AWAYSIS (IYLLR SINWIONWU SCREEN)

\& ON $100 \mathrm{MESH}$

\& ON 200 MESII

\& ON 325 MESH

\& THIROUGH 325 MIESII
0

0

6 TO 10

301094

MEDIN PNRTICLE UIAMETER (MICRONS)

SEDIGRANH ANALYSIS, 5 \& LESS IILAN 10 MICRONS

BULK UENSITY - LOOSE, GM/CU CM.

20 TO 40

BULK DENSITY - PACKEU, CM/CU CM

0.70 TO 0.80

SPECIFIC GRAVITY, GM/CU CM

1.2

SURFACE AREA, ${ }^{1}$ SO M/GNI

2.42

COLOR REFLECTANCE ${ }^{2}$

2 TO 3

80 TO 85

OIL ABSORPTION 3

22 TO 24 


$$
\begin{aligned}
& .92 \text { - osodry fo } 2 / 601 t I I \text {. } \\
& \text { so. }->\operatorname{m}+5.0 \mathrm{~W} \% \pi
\end{aligned}
$$
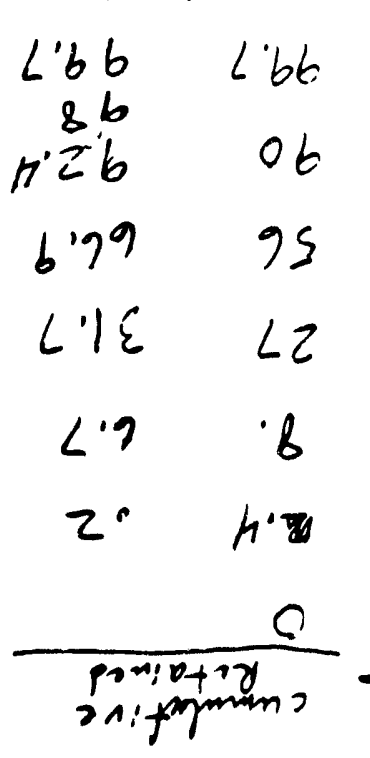

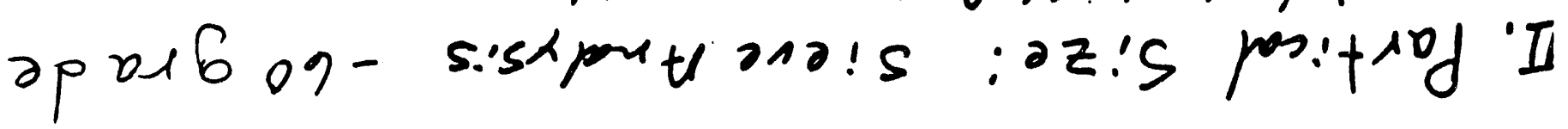

$\% 1^{\prime}-0^{2} X$

$\%+0^{\circ}-0^{2} \mathrm{~N}$

$\% 20$ - $0 \delta_{W}$

$\%=0^{\circ}-00 \mathrm{~J}$

$\% \varepsilon 0^{\circ}-{ }^{2} 0 ! 1$

$\% \varepsilon-\varepsilon_{0}^{2} / 4$

$250^{\circ}-40^{\circ}-\mathrm{SO}^{2} \mathrm{y} \mathrm{y}:$

$20266-20: 5$

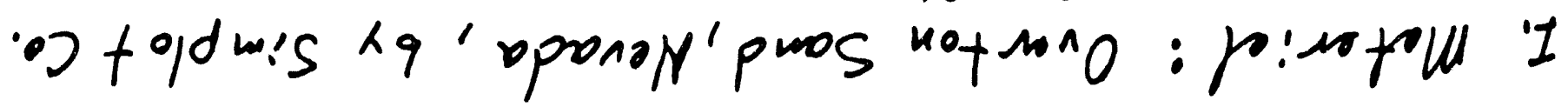
purs (นоนә^О) еอ!!!S 
Silica Flour

PAGF 1 OF 3

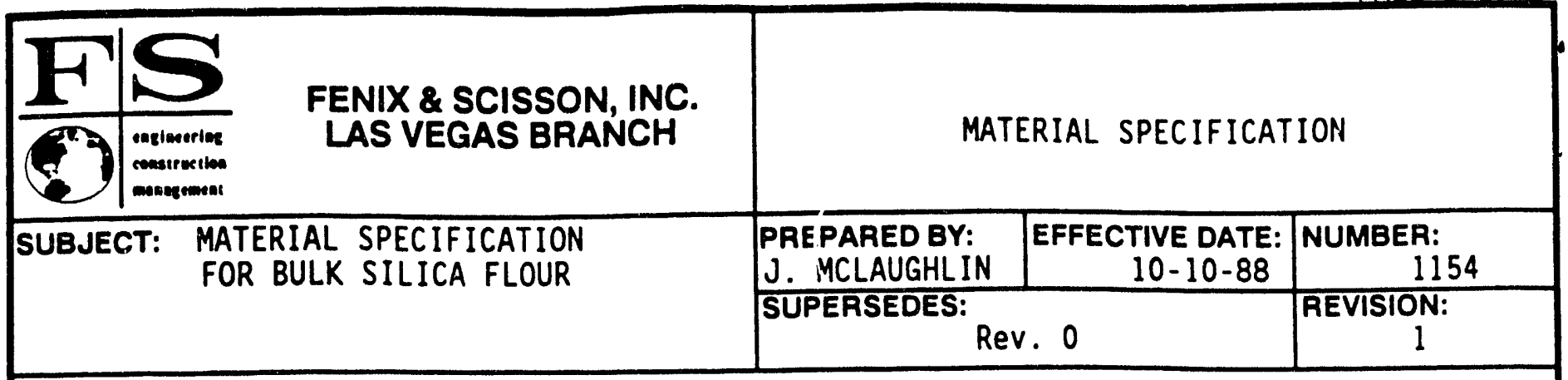

\subsection{SCOPE}

1.1 Material Specification for Bulk Silica Flour - The silica flour furnished under this specification will be used to prepare grout and concrete mixes for use in tunnels and drill holes at the Nevada Test Site (NTS).

\subsection{APPLICABLE SPECIFICATIONS, STANDARDS, CODES, AND DRAWINGS}

\subsection{ASTM C146-80}

\subsection{ASTM E11-87}

\subsection{REQUIREMENTS}

3.1 General - Silica flour is a powdered sand consisting primarily of silicon dioxide. It is used to stabilize the strength and permeability of cement.

3.1.1 Silicon Dioxide Content - Silicon dioxide content shall be 95 percent minimum. Test for silicon dioxide content shall be in accordance with ASTM C146-80.

3.1.2 Sieve Analysis - The silica flour shall conform to the following sieve analysis:*

Screen Size

No. 100

No. 200

No. 325

PAN

\section{Percentage Retained by Individual Screen}

$$
\begin{array}{r}
\text { Less than } 5 \% \\
5 \% \text { to } 15 \% \\
18 \% \text { to } 34 \% \\
50 \% \text { to } 60 \%
\end{array}
$$

*Sieve designation as per ASTM E11-87, "Wire-Cloth Sieves for Testing Purposes".

3.2 Compatibility With Existing Mix Designs - The silica flour shall be compatible with existing Waterways Experiment Station (WES) designed grout and concrete mixes. The material will be tested by WES to determine that it is compatible with their mixes and WES must approve the material for use prior to award. 


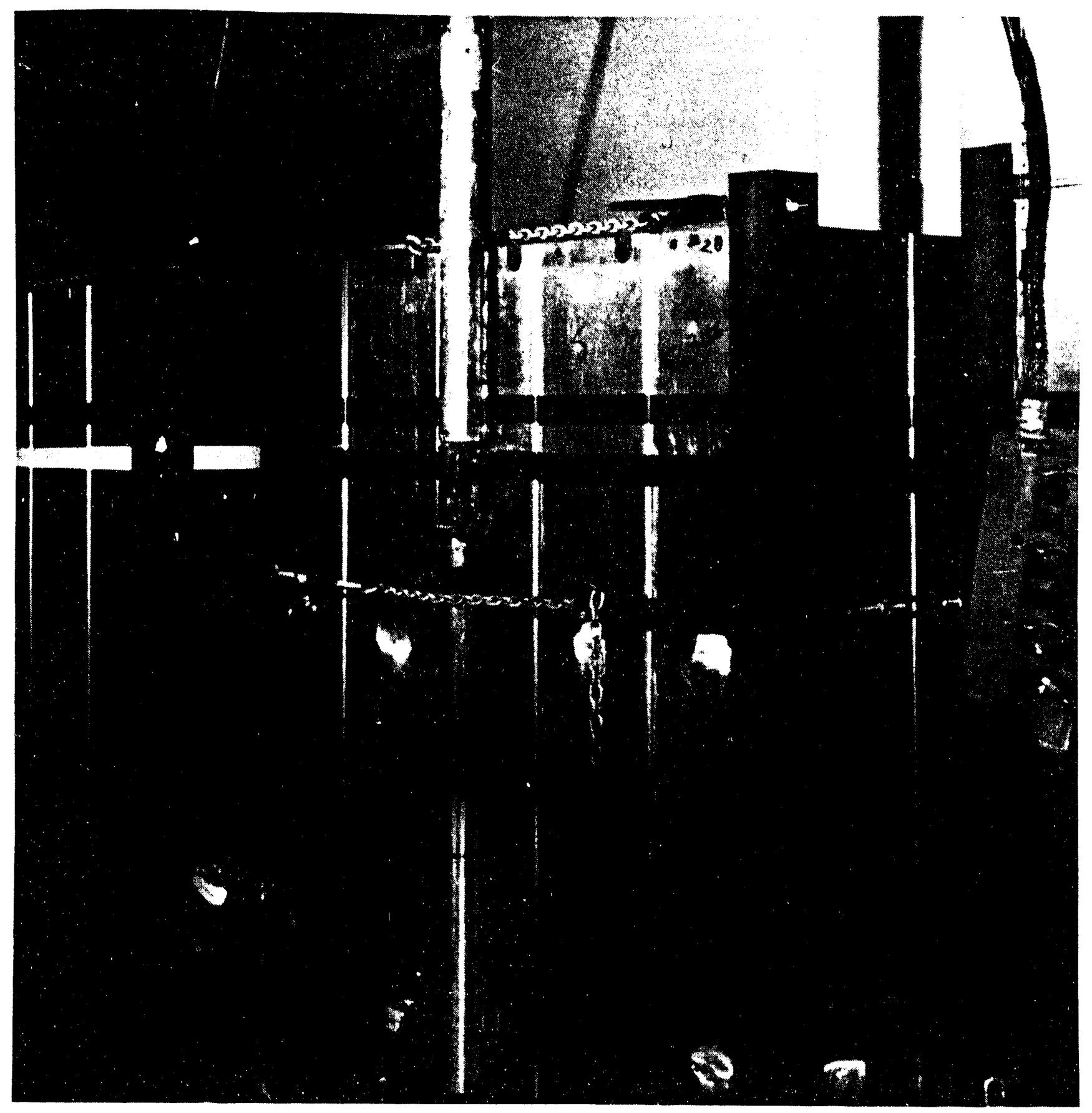

Figure 1. One station of the original Hydrogen Content Test Facility (HCTF), with an unshielded neutron sonde in place for calibration. Note that there are 15 cells in each station setup. 


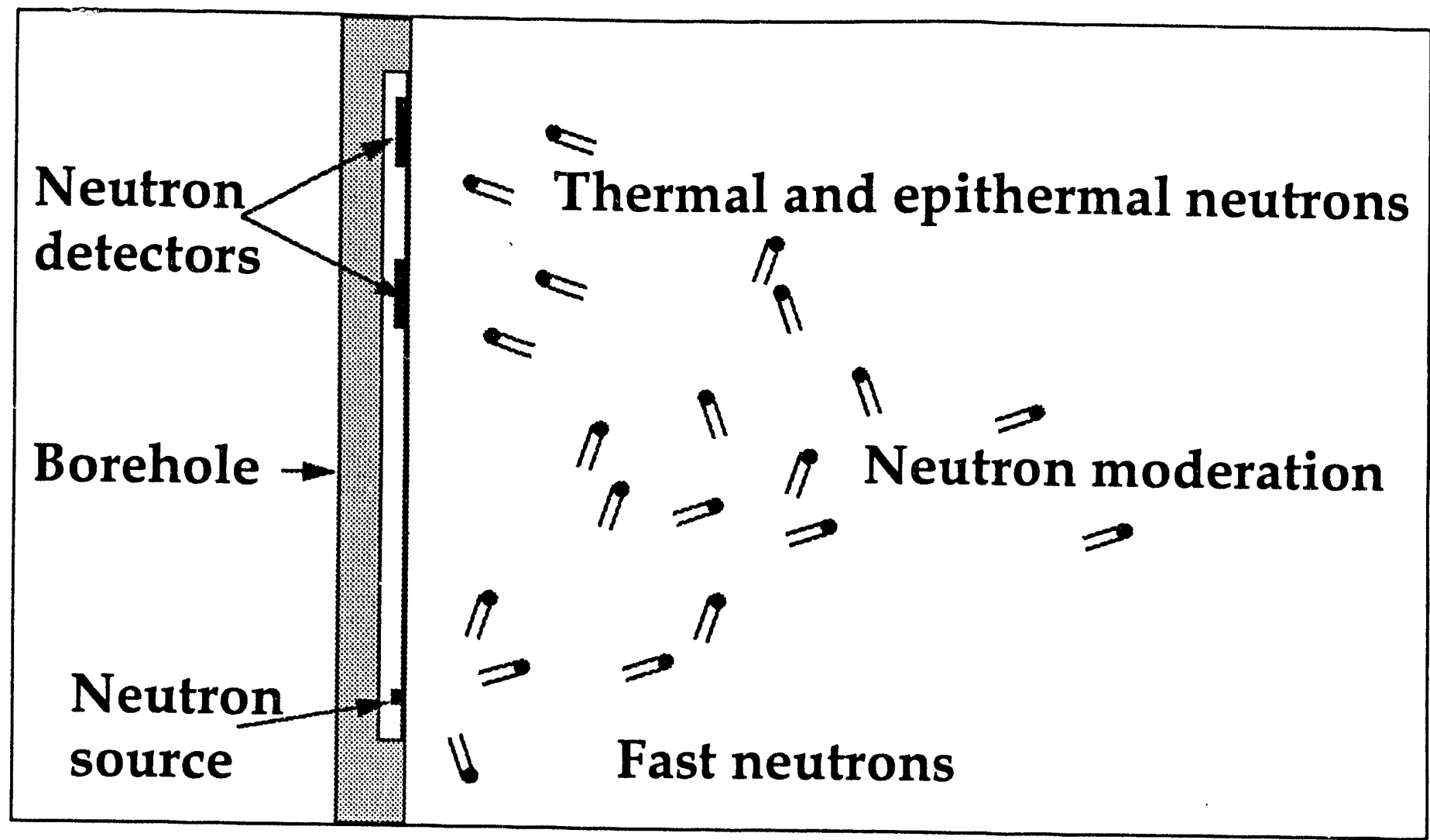

Figure 2. A sketch of a conventional neutron logging sonde (after Keys, 1990.) Note that two detectors are shown. Most sondes used at the NTS have only one detector. 


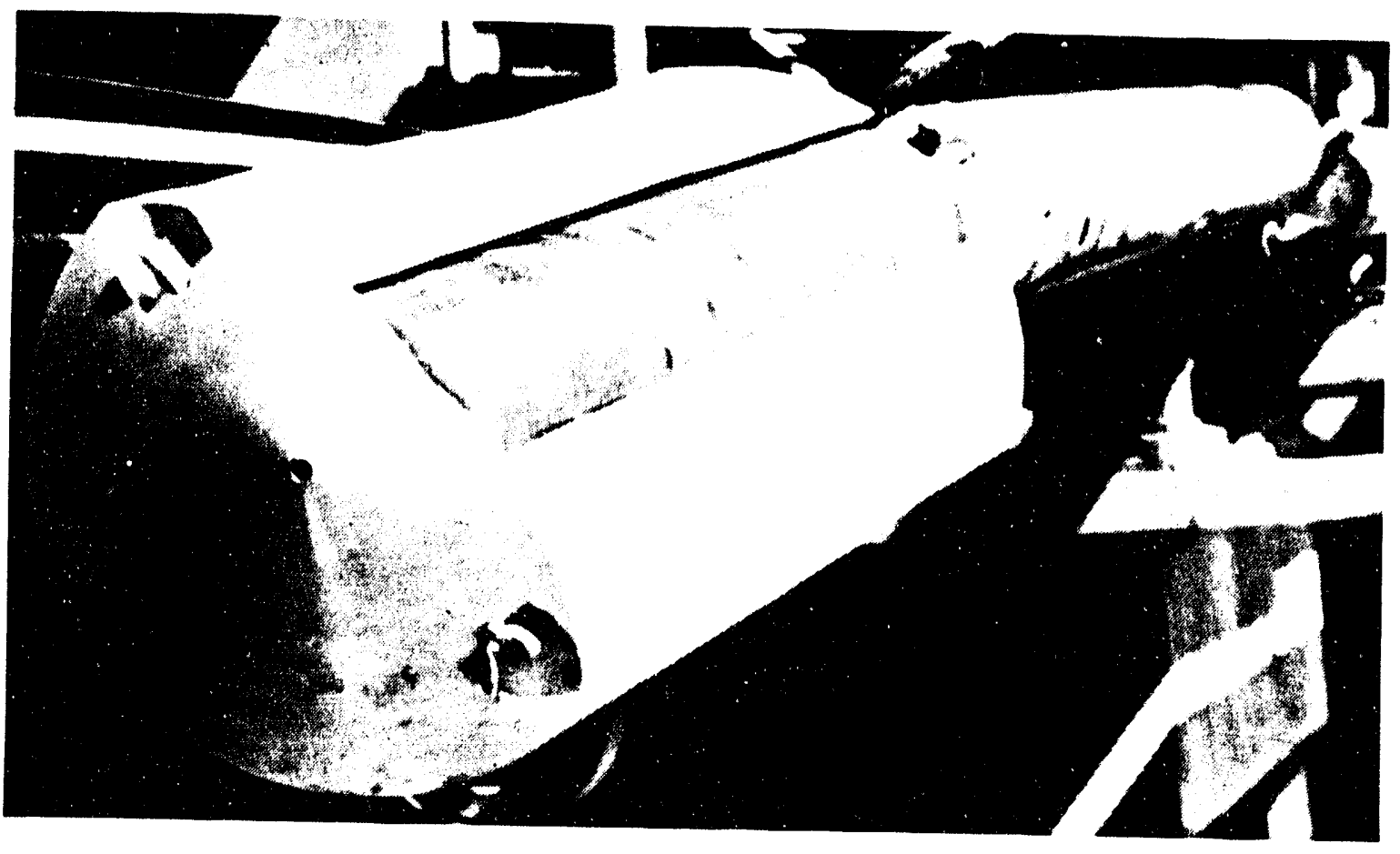

Figure 3. The ENP sonde. The shield surrounds the conventional neutron logging sonde. The gap-measuring wheel is visible just above the shield. Note the joint in the sonde, permitting the measuring part of the sonde to be forced against the borehole wall. 


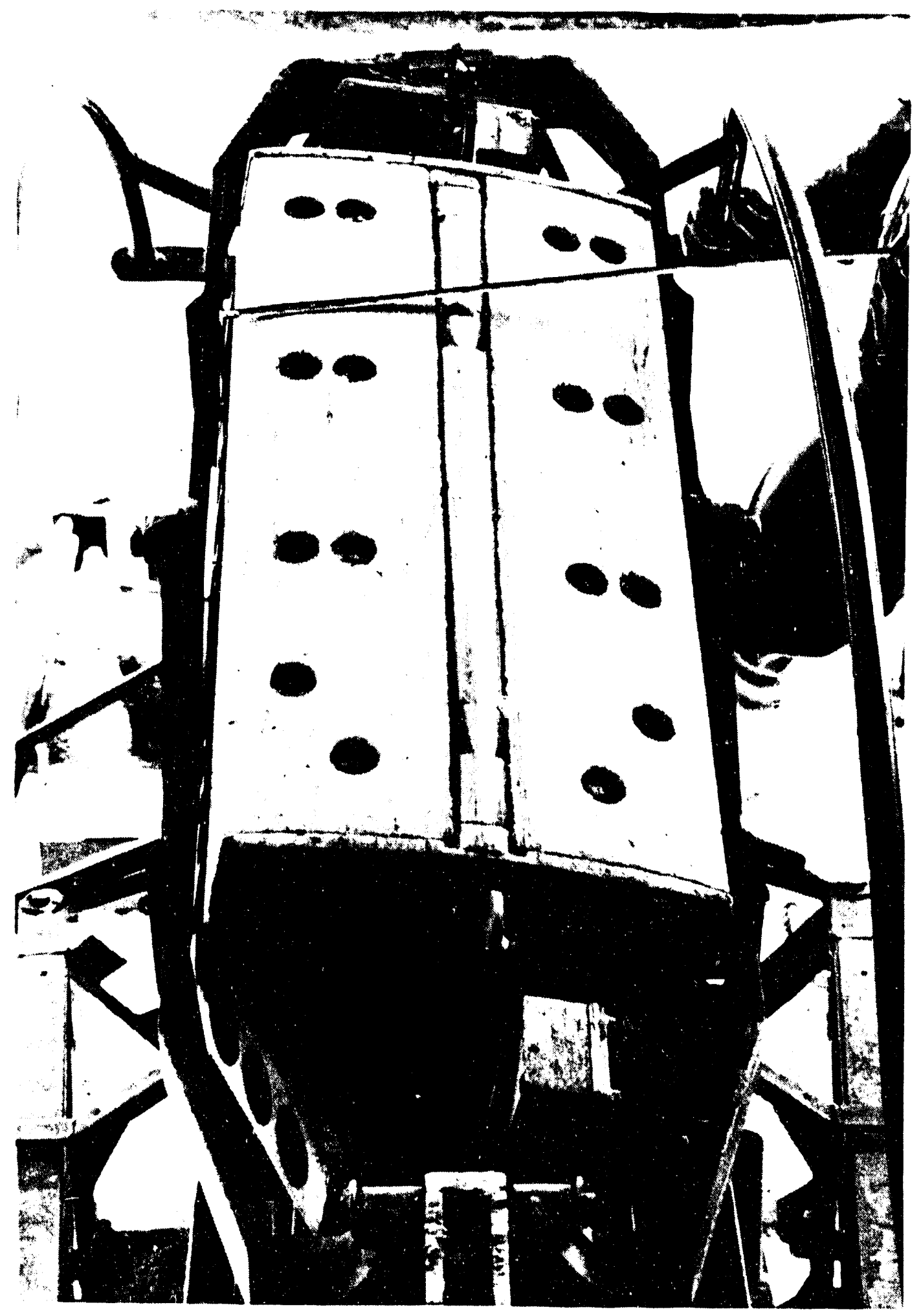

Figure 4. The ENS sonde. The large shield surrounds a conventional neutron sonde. Note the gap-measuring wheels at either end. The face shown is forced against the borehole wall. 


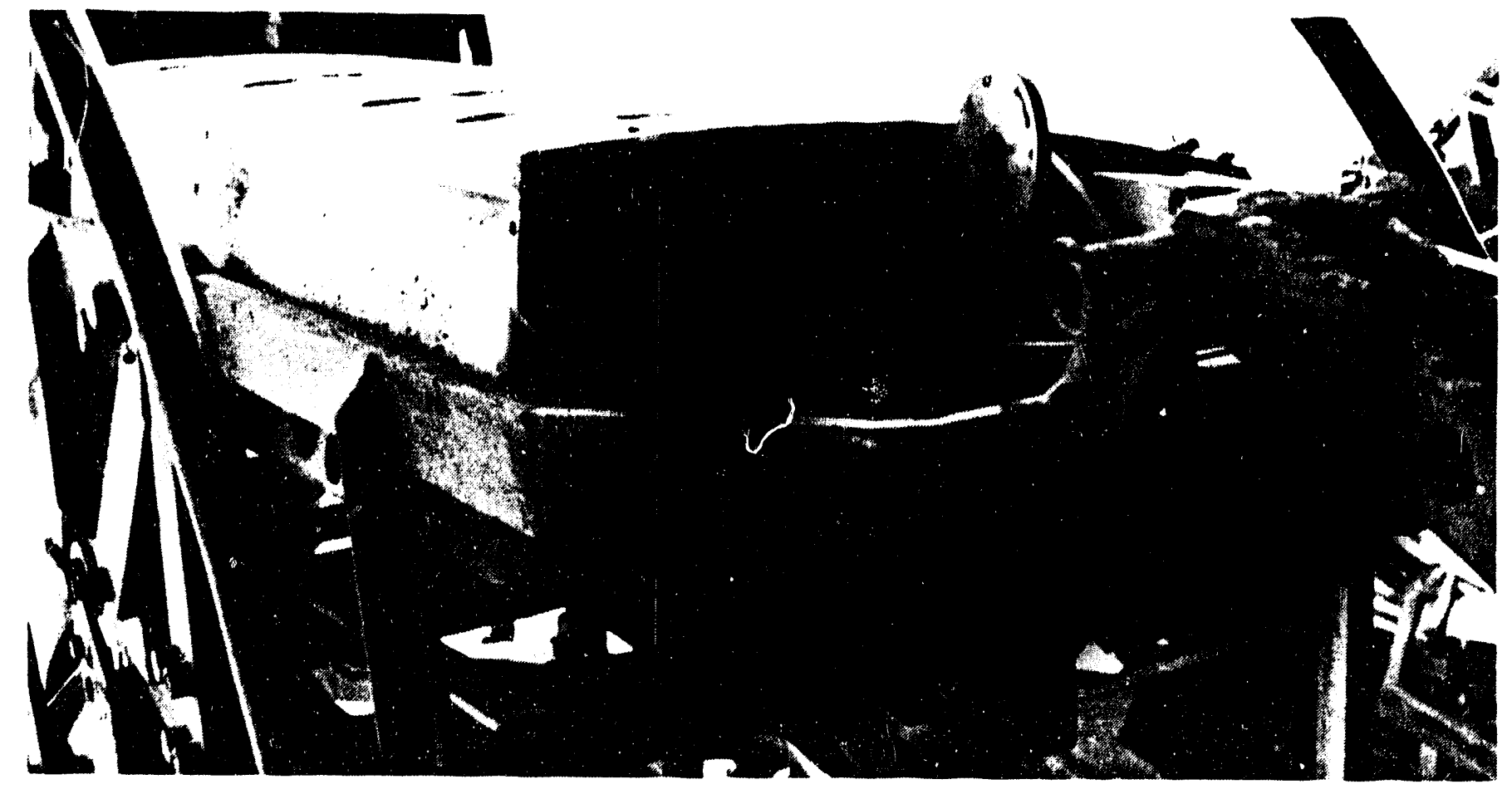

Figure 5. End view of the ENS sonde. Note the gap-measuring wheel and the thickness of the shield. 


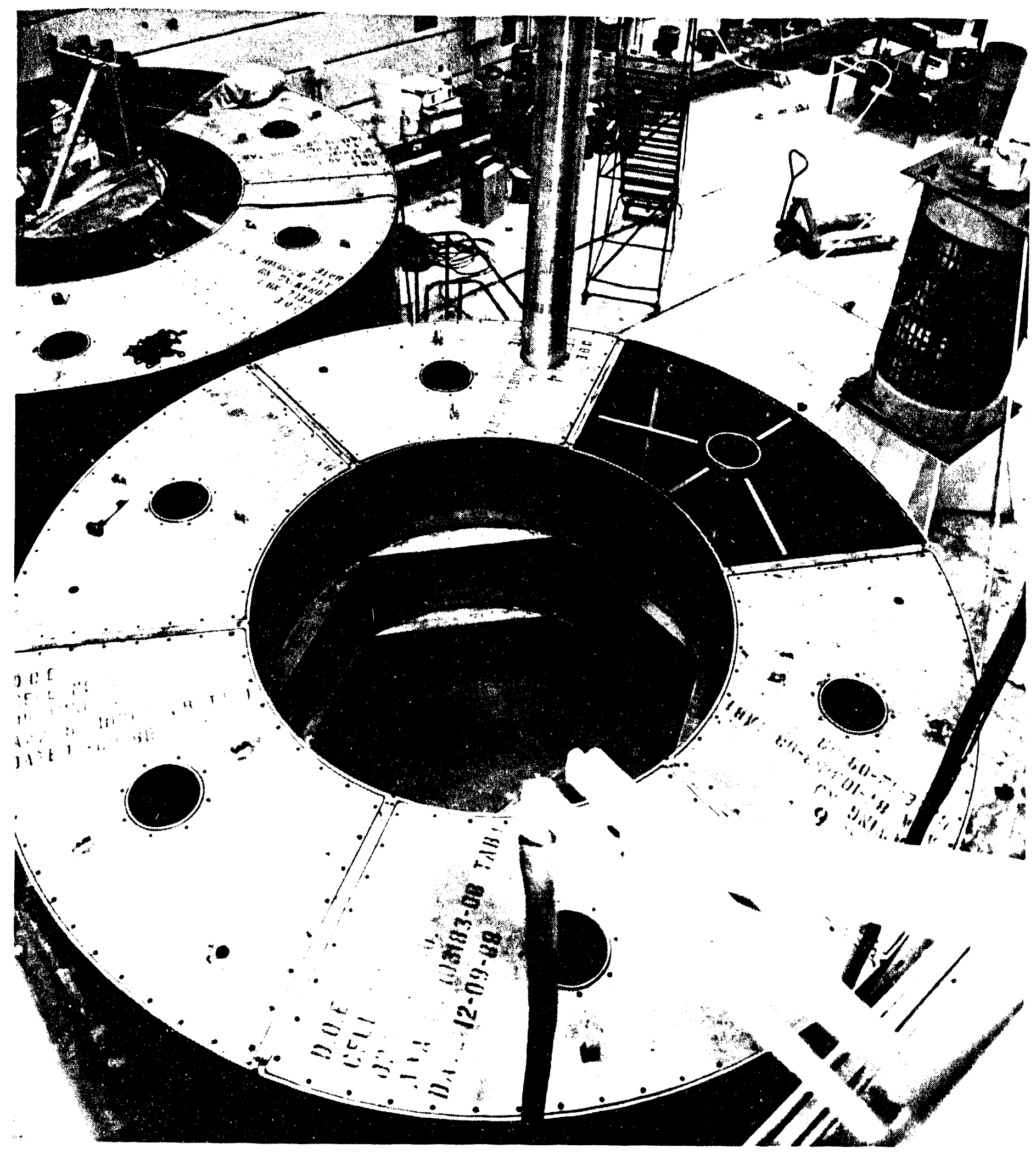

Figure 6. The new Hydrogen Content Test Unit (HCTU) during construction. Note the $30-\mathrm{cm}$ tube positioned in the uncovered cell, and the insert standing on one cell. The aluminum webs on the inner wall were removed after filling. 


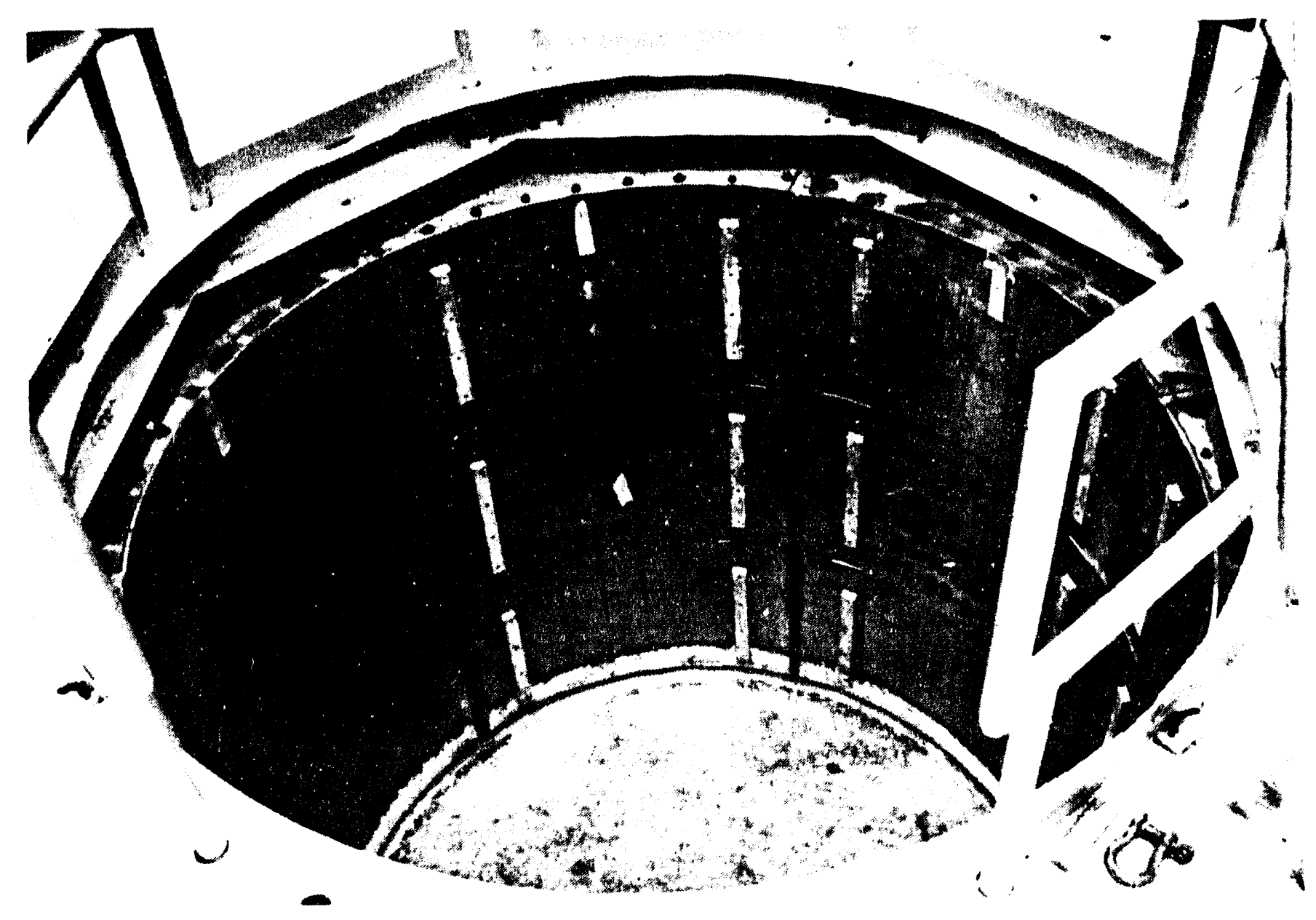

Figure 7. The completed HCTU. The webs have been removed from the inner wall, and mounting studs for tie sonde-holding jig attached. A safety scaffolding has been built over the cylinders. The $30-\mathrm{cm}$ holes are accessed through hatches in the scaffolding. 


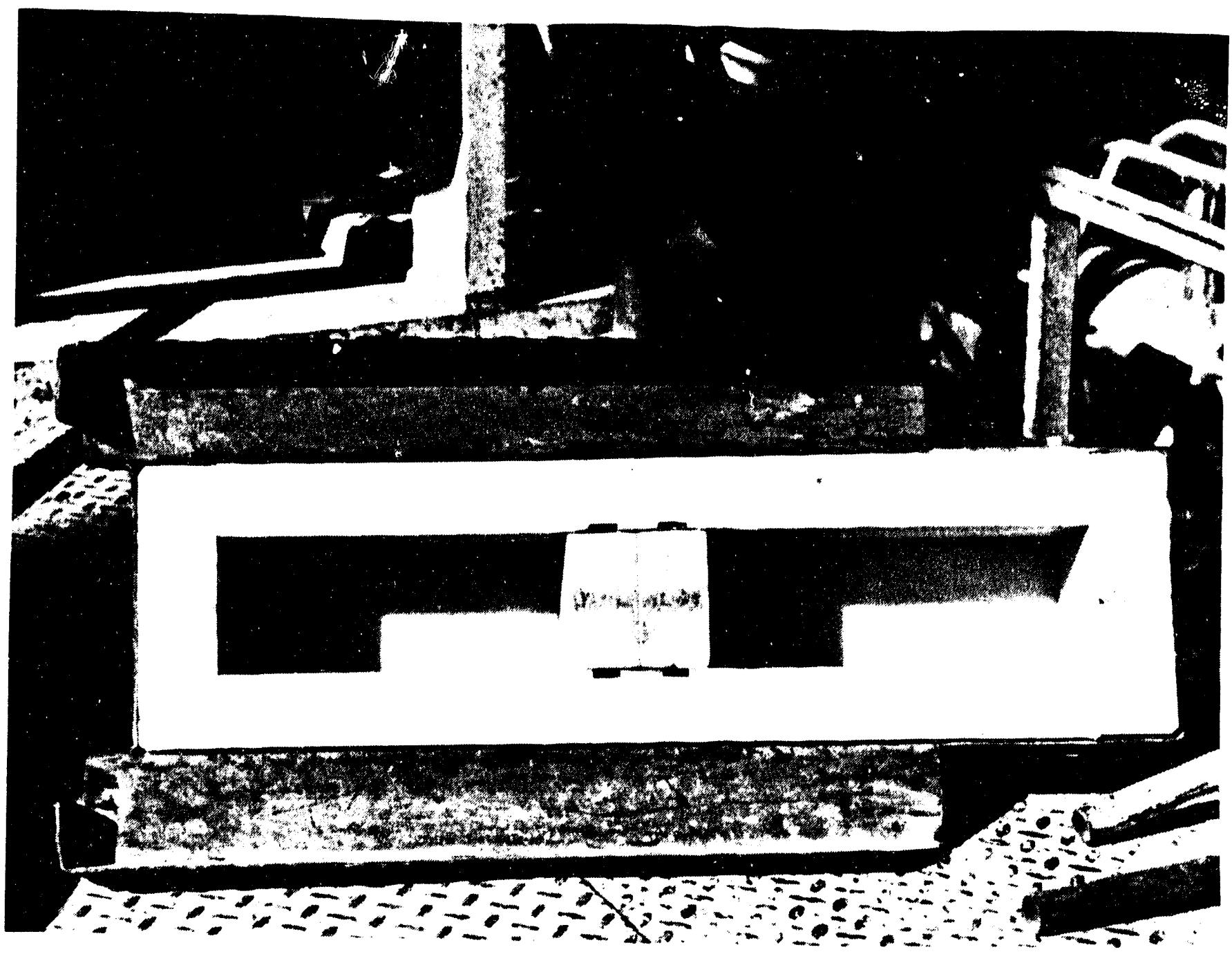

Fig. 8. A sonde's-eye view of the verifier. The tw/o $b$ ffles are in the down position. 


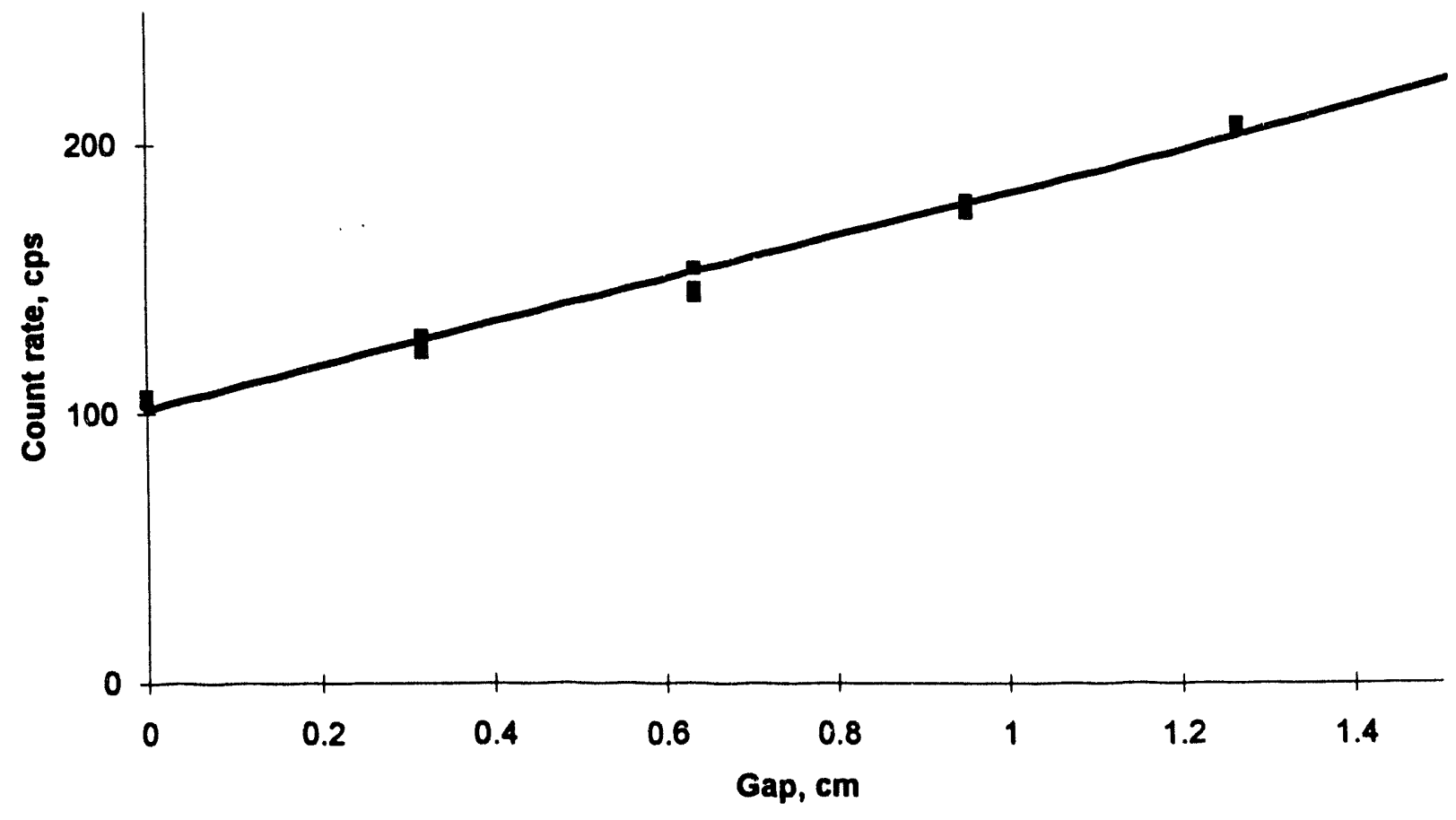

Figure 9. Count rate from the ENS vs gap in the dry hole on a typical cell (cell 8) of the HCTU. 


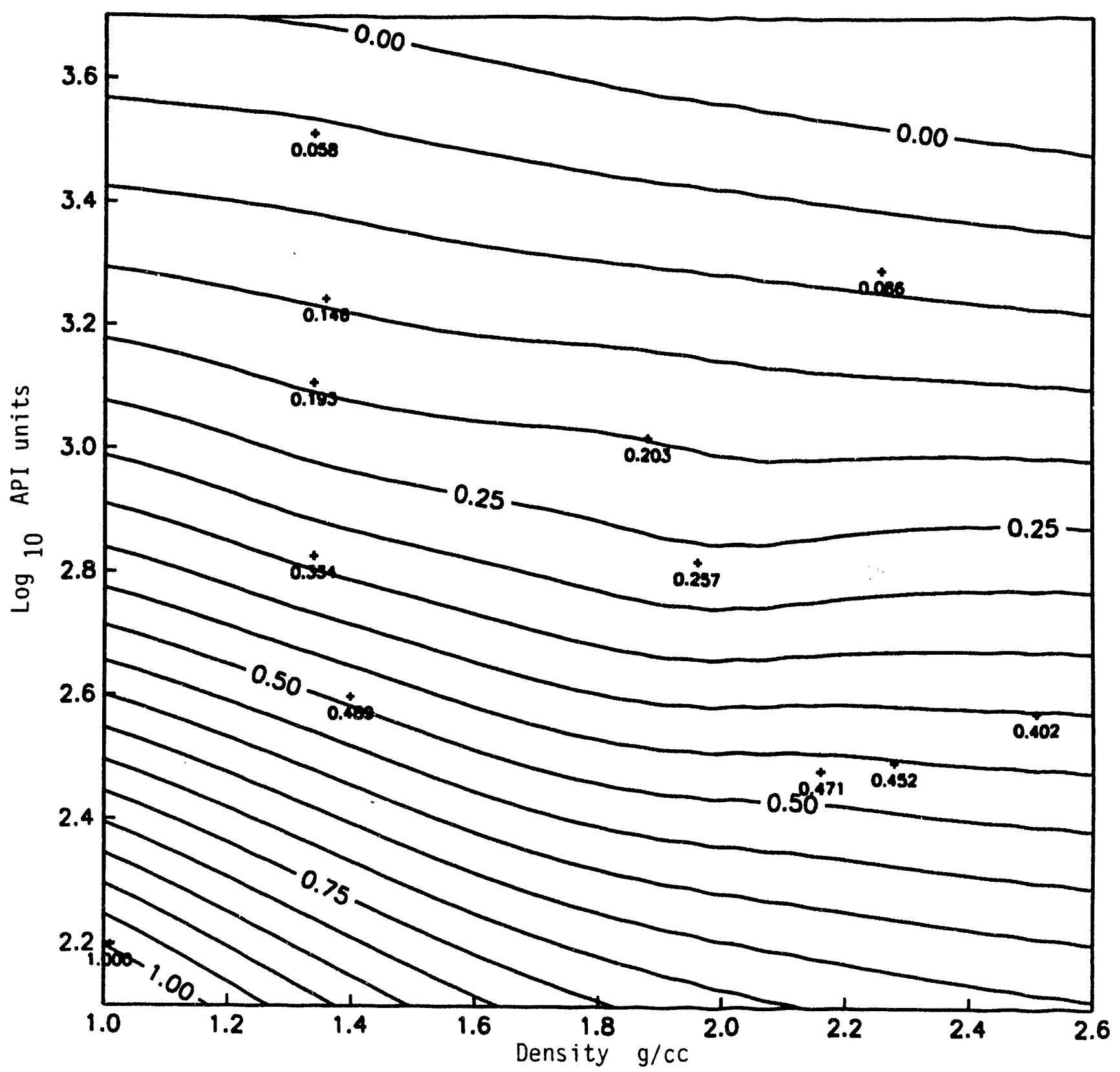

Figure 10. Grid of ENS data at zero gap under dry conditions in the 2.4-m-hole in the HCTU. Contours are volume fraction water. Measured data are posted. 


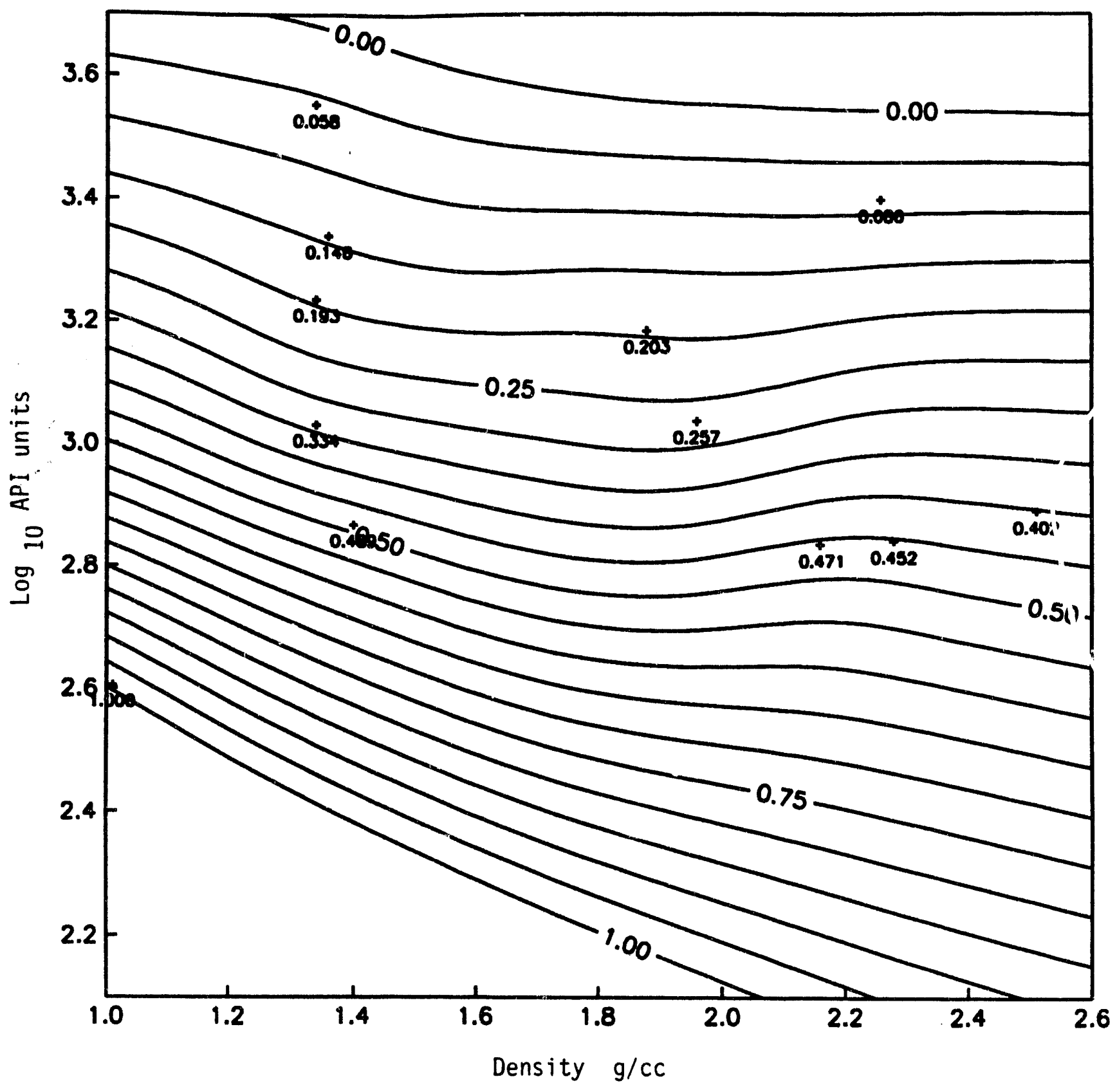

Figure 11. Grid of ENS data at $1.25 \mathrm{~cm}$ gap under dry conditions in the 2.4-m-hole in the HCTU. Contours are volume fraction water. Measured data are posted. 


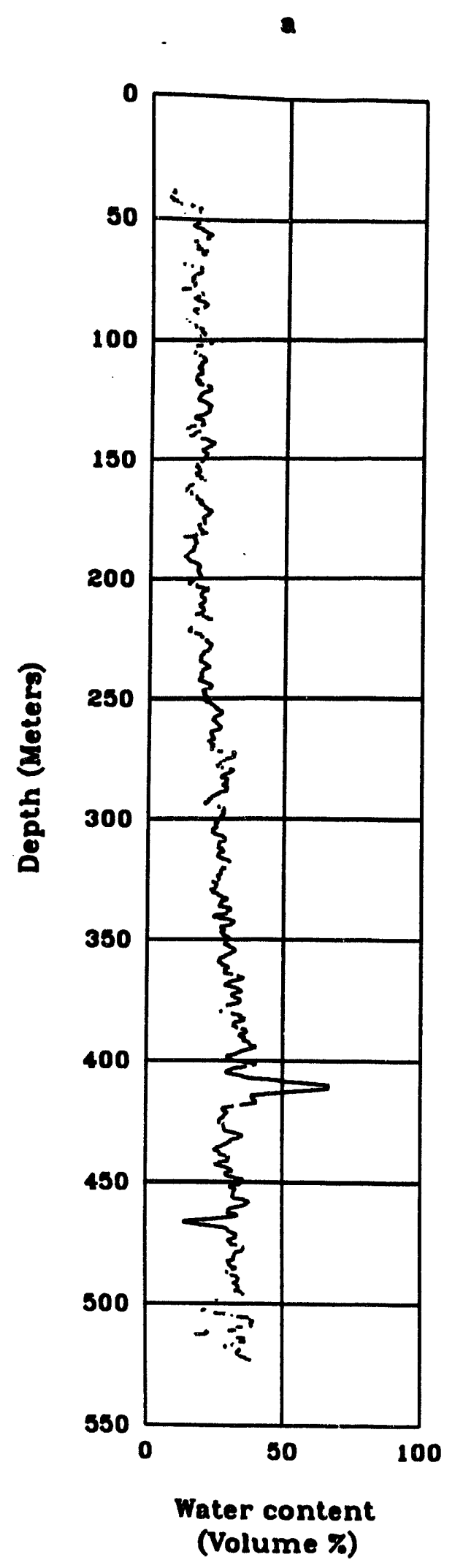

b

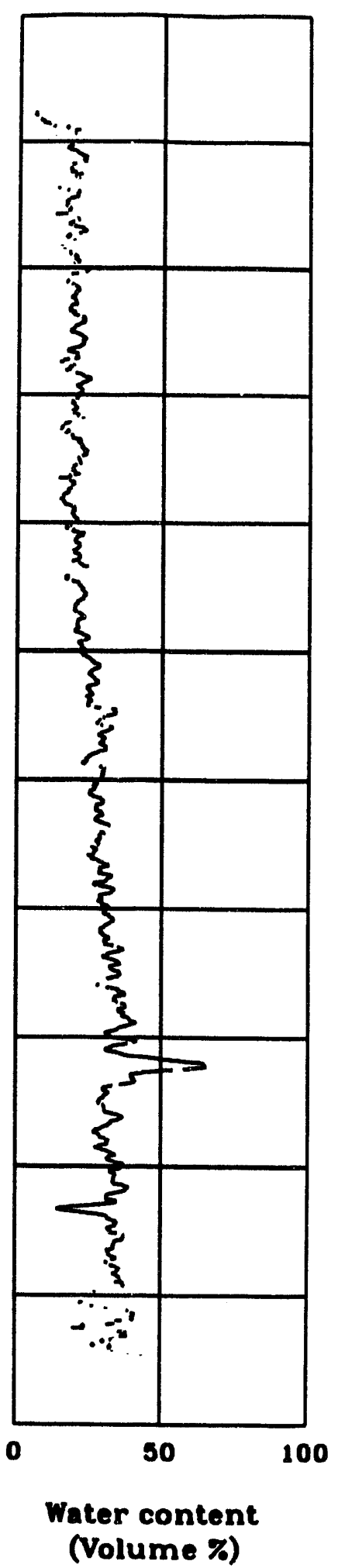

c

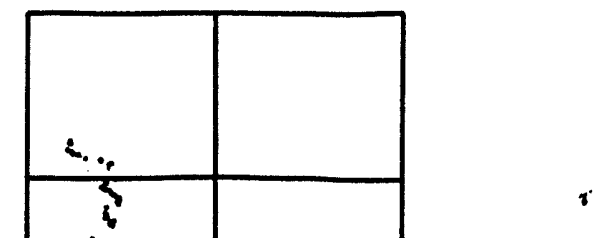

Figure 12. A neutron $\log$ in the NTS hole U2gi processed with (a) the original algorithm using HCTF data, (b) the grid algorithm using HCTF data and (c) the grid algorithm using HCTU data. Data smoothed with a 3-m boxcar filter. 

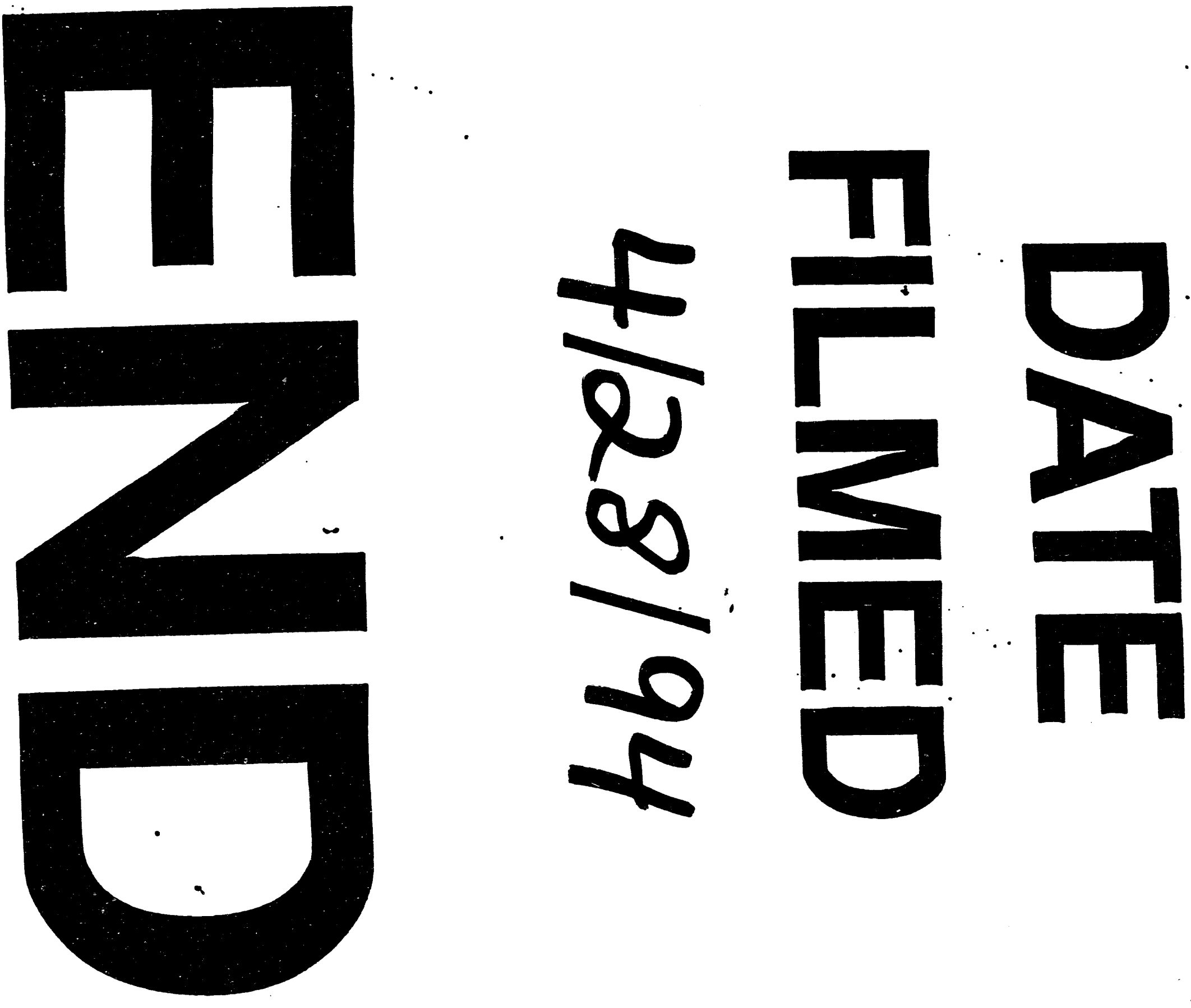
